\title{
DETECTION OF SAHARAN MINERAL DUST AEROSOL TRANSPORT OVER BRAZILIAN NORTHEAST THROUGH A DEPOLARIZATION LIDAR
}

\author{
Anderson G. Guedes ${ }^{1 *}$, Eduardo Landulfo ${ }^{2}$, Elena Montilla-Rosero ${ }^{3,5}$, Fábio J.S. Lopes ${ }^{2}$, Judith J. \\ Hoelzemann $^{3}$, José Henrique Fernandez ${ }^{3}$, Marcos P. A. Silva ${ }^{1}$, Renata S. S. Santos ${ }^{3}$, Juan L. \\ Guerrero-Rascado ${ }^{4}$, Lucas Alados-Arboledas ${ }^{4}$ \\ ${ }^{1}$ Graduate Program in Climate Sciences, Federal University of Rio Grande do Norte, Brazil, \\ andersongguedes@yahoo.com.br \\ ${ }^{2}$ Institute of Energy and Nuclear Research, Brazil \\ ${ }^{3}$ Department of Atmospheric and Climate Sciences, Federal University of Rio Grande do Norte, Brazil \\ ${ }^{4}$ Andalusian Institute for Earth System Research,University of Granada, Spain \\ ${ }^{5}$ School of Science, Physical Sciences Department, EAFIT University, Colombia
}

\begin{abstract}
In this study we present results of linear volume depolarization ratio profiles obtained by a depolarization lidar in operation in Natal, Brazil. The DUSTER system has 4 channels, namely: 1064, $532 \mathrm{~s} / \mathrm{p}$ and $355 \mathrm{~nm}$. This system is calibrated with a half-wave plate using the $\Delta 90^{\circ}$ methodology. The data obtained from this system is correlated with AERONET sunphotometer data, and, when available, CALIPSO satellite data. In addition a trajectory model (HYSPLIT) is used to calculate backward trajectories to assess the origin of the dust polluted air parcels. The objective is to create a transport database of Saharan dust.
\end{abstract}

\section{INTRODUCTION}

Long range transport of dust is a well-known phenomenon important to the atmospheric radiative budget with global impact on climate, air quality and human health [1-5]. It is estimated that about 3 billion tons of dust from the Sahara are transported each year and there are considerable suspicions about the influence of these aerosols on the Earth's radiative balance. Thus, creating an observational network for such an environmental occurrence is a challenge which requires a lot of resources. The existing observation networks [6] are concentrated regionally and there still are some gaps to be filled in order to obtain full global coverage.

In South America LALINET is one of these networks with the goal of measuring biomass burning plumes, volcanic ashes and dust transport into and out of the continent and more recently a lidar system (DUSTER) was developed at Natal$\mathrm{RN}\left(5^{\circ} 50^{\prime} 29^{\prime \prime} \mathrm{S}, 35^{\circ} 11^{\prime} 57^{\prime \prime} \mathrm{W}\right.$, sea level), in Brazil's northeastern region. DUSTER is a depolarization lidar system originally designed to detect and identify aerosol dust layers from Saharan Desert which are transported across the Atlantic Ocean. These observations are in coordination with an AERONET sunphotometer installed in Natal and also with CALIPSO's observation of these transport events.

The city of Natal is the capital of the state of Rio Grande do Norte (RN), located at the coast in Northeastern Brazil. The city and surroundings comprise a large diversity of different ecosystems, such as dune landscape, mangrove and Atlantic forests. This place has an area of approximately $167 \mathrm{~km}^{2}$ and an increasing population of about 877,662 inhabitants, according to the Brazilian Institute of Geography and Statistics (IBGE) in 2016. The climate of Natal is considered tropical wet with dry summer (austral) and an annual mean temperature of $26{ }^{\circ} \mathrm{C}$. The temperature may drop to $24{ }^{\circ} \mathrm{C}$ in winter and reach about $30{ }^{\circ} \mathrm{C}$ during summer, according to the National Institute for Meteorology (INMET). Solar irradiation yields elevated indices of up to 3000 hours of insolation per year, the average precipitation is $1465 \mathrm{~mm} /$ year (INMET) and occurs primarily from March through June with a maximum in April (265 mm).

The so called window of opportunity to observe dust transported into the continent at these latitudes is strongly influenced by the ITCZ (Intertropical Convergence Zone) migration 
putting this region under a variety of circulation patterns similar to those observed in the Caribbean counterpart around Barbados [5]. Due to these mechanisms the dust transport into this region occurs most likely during December, January and February (DJF) at $\approx 5^{\circ} \mathrm{N}$ and the less likely chance to observe this phenomenon should be in June, July and August (JJA) at $\approx 20^{\circ} \mathrm{N}$. This migration is strongly affected major oscillations such as ENSO and El Niño. The predominant observed transport takes place westwards of the African continent under strong influence of trade winds with some portions towards north over the Mediterranean sea. This pattern of transport follows a trend towards the Caribbean in JJA months and towards South America (SA) in DJF. This trend was tracked and confirmed by CALIPSO [7] and a seasonal dependence was also observed in the measured plume altitude, which was higher in JJA and slightly above the Planetary Boundary Layer (PBL) in DJF. In SA the transport over the Amazon basin is a known process [8].

\section{METHODOLOGY}

The DUSTER has 4 channels at $1064 \mathrm{~nm}, 532 \mathrm{~nm}$ (p), $532 \mathrm{~nm}$ (s) and $355 \mathrm{~nm}$ coupled to a $300 \mathrm{~mm}$ Cassegranian Carbon-Plastic telescope. Each channel has interference filters to block sunlight background with bandwidths of ( $2 \mathrm{~nm}$ FWHM at each channel). The laser source emits at $1064 \mathrm{~nm}$, $532 \mathrm{~nm}$ and $355 \mathrm{~nm}$, with energy per pulse of about $300 \mathrm{~mJ}, 150 \mathrm{~mJ}$ and $90 \mathrm{~mJ}$, respectively. The laser repetition rate is $20 \mathrm{~Hz}$ and pulse duration is $(7 \pm 2)$ ns. The detection box has an Avalanche Photo-diode (APD) for $1064 \mathrm{~nm}$ and 3 photomultipliers, for both polarizations at $532 \mathrm{~nm}$ and $355 \mathrm{~nm}$. Their signal is digitized by a transient recorder operating in analog and photoncounting modes (Licel model TR20-80, bandwidth $\square 10$ - $250 \mathrm{MHz}$ ) (Figure 1).

The depolarization measurement capability of DUSTER let to distinguish and to identify unambiguously the volume linear depolarization ratio parameters. This parameter is defined as the ratio of the cross polarized lidar return signal to the parallel-polarized backscatter signal, the signals are selected in the optical reception box by means of a polarizing beam splitter cube (PBC).
To retrieve the linear volume depolarization ratio $\delta_{v}$ the $\Delta 90^{\circ}$ calibration [9] method was implemented using $a \lambda / 2$ plate (HWP) for retrieving the amplification factor $\eta^{*}$. The HWP was located in front of laser emitter and several measurements were done under clear sky conditions to get the amplification due to polarization changes.

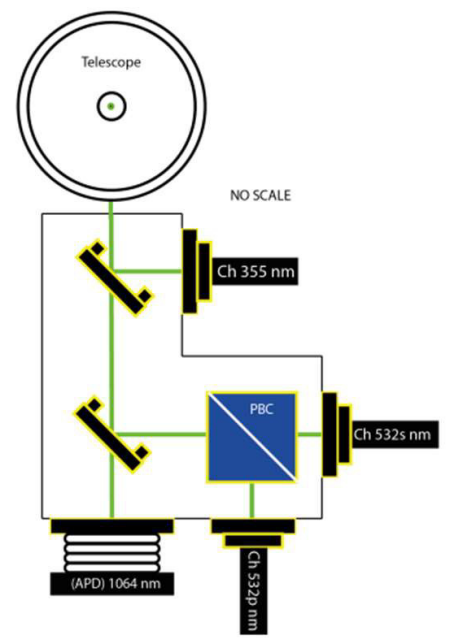

Figure 1. Sketch of the receiver unit of lidar system DUSTER with the depolarization channel $532 \mathrm{~nm}$, labeled.

\subsection{Sunphotometer}

The AErosol RObotic NETwork (AERONET) is an international network of ground-based sun photometers that provides automatic sun and sky scanning measurements. The sunphotometer (model CIMEL CE318 radiometer included in AERONET) located at Natal is setup about $200 \mathrm{~m}$ away from the DUSTER Lidar system. This performs radiances measurements in order to retrieve the Aerosol Optical Thickness for aerosols at several wavelengths. Besides the AOD, it is possible to obtain the aerosol size distribution (AE), the phase function, single scattering albedo and extinction-to-backscatter ratio. This procedure assures measurement accuracy to within $13 \%$.

\section{RESULTS}

DUSTER started its operation in February 2016 following LALINET's measurement protocol, 
with regular measurements on most days of week. Initially, the measurements were carried out to check system performance and depolarization calibration procedure. By $\Delta 90^{\circ}$ calibration a $\eta^{*}$ value of 0.35 was retrieved using laser line filters to $532 \mathrm{~nm}$ with FWHM bandwidth of $2 \mathrm{~nm}$. On March 11 a distinctive layer was observed at 2.5 to $\approx 3 \mathrm{~km}$ which was identified as mostly consisting of dust aerosols, due to the DUSTER measured a volume linear depolarization ratio in the dust layer (2.5 to $3 \mathrm{~km}$ height) of the $0.17 \pm 0.01$ for $532 \mathrm{~nm}$ (Figure 2).

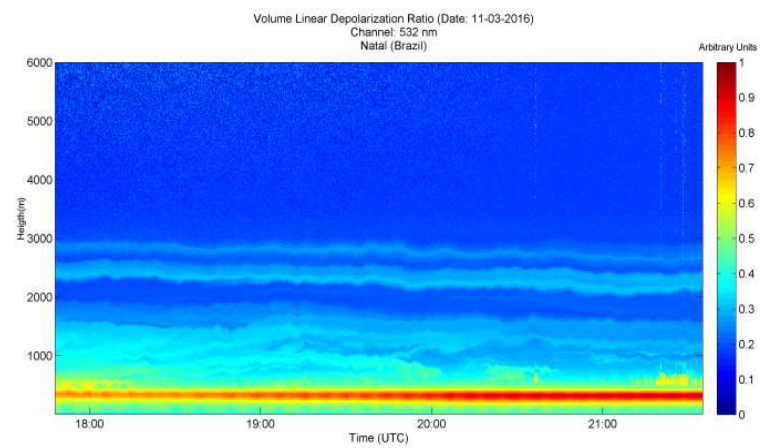

Figure 2. Volumetric Depolarization Ratio obtained with DUSTER on March 11 (17:48 UTC-21:35UTC) analyzing the upper plume with a strong possibility of being dust transported over the ocean.

One local aspect worth mentioning is the fact that observing these plumes becomes a challenge as they move away due to a steady wind field present in the Natal area, certainly an aspect easily recognizable by the presence of trade Winds. The presence of low clouds also gives an additional difficulty to the observing site.

Synoptically, according to the automatic INMET meteorological station in Natal, this day was a clear day without precipitation, with an average temperature of $29^{\circ} \mathrm{C}$, ranging from $27^{\circ} \mathrm{C}$ in the early morning to $29^{\circ} \mathrm{C}$ at $21 \mathrm{UTC}$ and a relative humidity of $63-88 \%$. The predominant wind direction were from Southeast and its velocity 3.7 $\mathrm{m} / \mathrm{s}(18 \mathrm{UTC})-3.1 \mathrm{~m} / \mathrm{s}$ (22 UTC). Solar radiation were $2476 \mathrm{~kJ} / \mathrm{m}^{2}$ (18 UTC) - $78.41 \mathrm{~kJ} / \mathrm{m}^{2}$ (21 UTC).

The Natal AERONET sunphotometer station data allow to obtain diurnal Angström Exponent (AE) (note: days where data were collected) during the first semester of 2016. Some periods in February, mid March and early June are corresponding to dust aerosol (Figure 3). In April it was not possible to obtain data with the instrument due to technical problems. The low AE values suggest the presence of an aerosol compatible with desert aerosols.

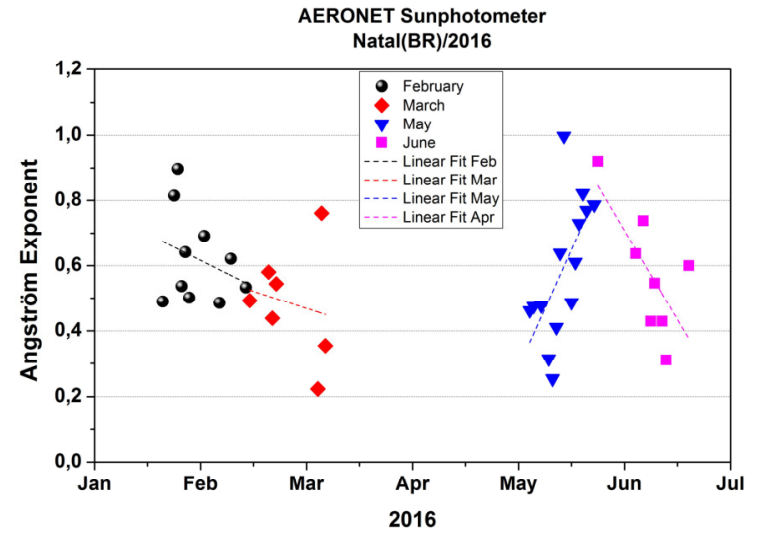

Figure 3. Variation of AE for the months of February to June.

In order to validate the source of these dust plumes a HYSPLIT trajectory model simulation was carried out to provide back trajectories which ended on March 11 and described the air masses from 10 days back predominantly to the Northern African West Coast as shown in Figure 4.

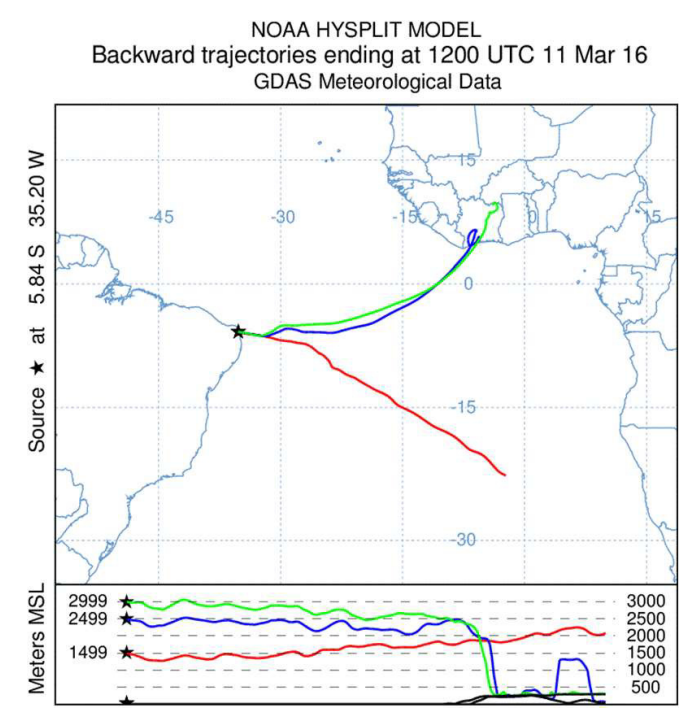

Figure 4. Dust track direction and trajectory from Saharan region towards Natal obtained with HYSPLIT Model. 
The shortest distance from the CALYPSO satellite in relation to the DUSTER site for the day of March 11 was $194 \mathrm{~km}$, a good data correlation was not recommendable.

\section{CONCLUSIONS}

The data obtained with DUSTER in the first halfof 2016 have shown episodes where the aerosols travelling over the city of Natal are compatible with dust. The 2017 campaign (Dec 2016, Jan 2017 and Feb 2017) and improvements in the depolarization calibration process will contribute to more accurate analysis with the equipment.

\section{ACKNOWLEDGEMENTS}

We acknowledge the Conselho Nacional de Desenvolvimento Científico e Tecnológico $\mathrm{CNPq} / \mathrm{MCTIC}$ for the research grants under process number 400430/2014-2 and the research project CNPq 477713/2013-0. Also, we thank the Coordenação de Aperfeiçoamento de Pessoal de Nivel Superior CAPES/MEC for their support via a doutorado-sanduiche research grant number 88881.133708/2016-01.

\section{References}

[1] Mahowald, N.M., Ballantine, J.A., Feddema, J., and Ramankutty, N., "Global trends in visibility for dust sources", Atmospheric Chemistry and Physics 7 (12), 3309-3339 (2007).

[2] Antón, M., Valenzuela, A., Román, R., Lyamani, H., Krotkov, N., Arola, A., Olmo, F. J., and Alados- Arboledas, L., "Influence of desert dust intrusions on ground-based and satellite-derived ultraviolet irradiance In Southeastern Spain", journal of Geophysical Research: Atmospheres 117 (D19), (2012).

[3] DeMott, P.J., Prenni, A.J., Liu, X., Kreidenweis, S.M., Petters, M.D., Twohy, C.H., Richardson, M. S., Eidhammer, T., and Rogers, D. C., "Predicting global atmospheric ice nuclei distributions and their impacts On climate", Proceedings of the National Academy of Sciences 107 (25), 11217-11222 (2010).
[4] Longueville, F. D., Hountondji, Y. C., Henry, S., and Ozer, P., "What do we know about e effects of desert Dust on air quality and human health in west Africa compared to other regions", Science of The Total Environment 409 (1), 1-8 (2010).

[5] Prospero, J. M., Collard, F.-X., Molinié J., and Jeannot, A., "Characterizing the annual cycle of african Dust transport to the caribbean basin and south america and its impact on the environment and air quality", Global Biogeochemical Cycles 28 (7), 757773 (2014)

[6] Guerrero-Rascado, J. L., Landulfo, E., Antuña, J. C., de Melo Jorge Barbosa, H., Barja, B., Bastidas, A. E., Bedoya, A. E., da Costa, R.F., Estevan, R., Forno, R., Gouveia, D.A., Jiménez, C., Larroza, E. G., da Silva Lopes, F.J., Montilla-Rosero, E., Arruda Moreira, G., Nakaema, W. M., Nisperuza,D., D., M., Otero, L., Papandrea, S., Pallota, J. V., Pawelko, E., Quel, E. J., Ristori, P., Rodrigues, P. F., Salvador, J., S. Anchez, M. F., and Silva, A., "Latin American network (LALINET) For aerosol research: Diagnosis on network instrumentation", Journal of Atmospheric and Solar-Terrestrial Physics 138-139, 112-120 (2016).

[7] Z. Liu, A. Omar, M. Vaughan, J. Hair, C. Kittaka, Y. Hu, K. Powell, C. Trepte, D. Winker, C. Hostetler, R. Ferrare, and R. Pierce, Calipso lidar observations of the optical properties of saharan dust: a case study of long-range transport, J. Geophys. Res. 113 (2008), D07207.

[8] R. Swap, M. Garstang, S. Greco, R. Talbot, and P. Kallberg, Saharan dust in the amazon basin, Tellus 44B (1992), 133-149.

[9] Freudenthaler, V., "On the e effects of polarizing optics on lidar signals and the $\Delta 90$ calibration", Atmospheric Measurement Techniques 9 (9), 4181-4255 (2016). 